ISSN = 1980-993X - doi:10.4136/1980-993X
www.agro.unitau.br/ambi-agua
E-mail: ambi-agua@agro.unitau.br
Tel.: (12) 3625-4116

\title{
Mapping and monitoring land cover types in Corumbiara area, Brazilian Amazônia, using Landsat TM and JERS-1 SAR multitemporal data
}

(doi:10.4136/ambi-agua.39)

\author{
Yosio E. Shimabukuro, Raimundo Almeida-Filho, Tatiana M. Kuplich, Ramon \\ M. de Freitas
}

\author{
Instituto Nacional de Pesquisas Espaciais (INPE) \\ Av. dos Astronautas, 1758, São José dos Campos, SP, 12227-010, Brasil \\ E-mail: \{yosio, rai, tmk, ramon\}@dsr.inpe.br
}

\begin{abstract}
This paper discusses the use of a Landsat Thematic Mapper (TM) and JERS-1 Synthetic Aperture Radar (SAR) time-series for mapping and monitoring land cover types in a test site in the region of Corumbiara, Rondônia State, western Brazilian Amazônia. In order to support JERS-1 data analysis, land cover maps were obtained by digital classification of Landsat TM images acquired from 1993 to 1997 period, following a procedure based on image segmentation, unsupervised classification, and post-classification image edition. The comparison of these products with JERS-1 temporal images shows that clear-cut areas are well-identified presenting a low backscattering response as expected. On the other hand, areas that have been cleared and even burned but with remaining forest material left on the ground present high backscattering response. Considering these observations and user interpretation expertise, temporal SAR images present an effective source of information for mapping and monitoring deforestation, especially in areas covered by clouds with restricted use of optical data.
\end{abstract}

Keywords: Landsat TM; JERS-1 SAR; land cover map; multitemporal analysis; digital classification; Amazonia region.

\section{Mapeamento e monitoramento dos tipos de cobertura da terra na área de Corumbiara, Amazônia brasileira, utilizando dados multitemporais do TM Landsat e do SAR JERS-1}

\section{RESUMO}

Este artigo discute o uso de uma série temporal de imagens do sensor TM do Landsat e do radar de abertura sintética (SAR) do JERS-1 para o mapeamento e monitoramento dos tipos de cobertura da terra numa área teste na região de Corumbiara, no Estado de Rondônia, oeste da Amazônia brasileira. Como suporte à análise dos dados do JERS-1, mapas da cobertura da terra foram obtidos por meio da classificação digital das imagens TM do Landsat adquiridas no período de 1993 a 1997, de acordo com um procedimento baseado na segmentação de imagem, classificação não supervisionada, e edição da classificação. A comparação desses produtos com as imagens multitemporais do JERS-1 mostra que as áreas cortadas são bem identificadas apresentando resposta baixa de retroespalhamento como esperado. Por outro lado, áreas desflorestadas e mesmo queimadas mas com restos de material 
da floresta deixadas no solo apresentam resposta alta de retroespalhamento. Considerando estas observações e a experiência dos fotointerpretes, as imagens temporais do SAR apresentam uma fonte de informações efetivas para o mapeamento e monitoramento do desflorestamento, especialmente em áreas cobertas por nuvens que restringem o uso de dados ópticos.

Palavras-chave: Landsat TM; JERS-1 SAR; mapa de cobertura da terra; análise multitemporal; classificação digital; região Amazônica.

\section{INTRODUCTION}

There is an increasing need for accurate mapping of forest conservation status. Since 1988 Brazilian Amazônia is monitored by the PRODES (Brazilian Estimate of Deforestation) Project (INPE, 2007), and results of this project have become available online, including yearly deforestation rates (http://www.obt.inpe.br/prodes/index.html). Maps of deforestation and rates of deforestation are produced by interpretation of Landsat Thematic Mapper (TM) images and, although the PRODES has been conducted successfully, it relies on optical remote sensing data, subject to the near-constant cloud coverage over the tropics.

In the Brazilian Amazônia, deforestation process can follow different methods, but it is common the removal of vegetation cover by the use of chain saws, with use of fire to complete the clearing process. The smoothed surface of the cleared terrains usually presents low radar return and, consequently, deforested areas will appear in dark shades in Synthetic Aperture Radar (SAR) images. However, where radar images are acquired before the clearing process has been concluded, presence of woody material on the ground will produce strong radar backscatters. Thus, contrary to the first case, uncompleted deforested areas will appear in light shades in radar scenes, as discussed by Stone and Woodwell (1988) and Almeida Filho et al. (2005). The mechanism of corner reflection between soil and trees left standing on the ground is responsible for the enhanced response, allowing the discrimination of this step of the deforestation process from the remaining land covers.

This study follows a previous one by Shimabukuro et al. (2007), which evaluated by statistical analysis the correlation among different land use/land cover classes identified in Landsat TM optical and SAR data acquired simultaneously in a study area. As results of this quantitative approach were very promising, we followed with a qualitative analysis of a multi-temporal JERS-1 time series, mainly for evaluating the discrimination ability of SAR images to specific deforestation steps. Thus, the present study aims to understand the role of the most significant terrain variables involved in remote deforestation mapping, thereby contributing to improve the use of SAR image as an operational system to map land use/land cover under the conditions and practices currents in the Brazilian Amazônia.

\section{STUDY AREA}

The study area is located in the south of Rondônia State, western Brazilian Amazônia (Figure 1), and comprises approximately $4,000 \mathrm{~km}^{2}$. The region is mainly covered by dense tropical forest that has been partially cleared over the past thirty years. Ten JERS-1 SAR and five Landsat TM images were acquired between 1993 and 1997 (Table 1) over this study area. 


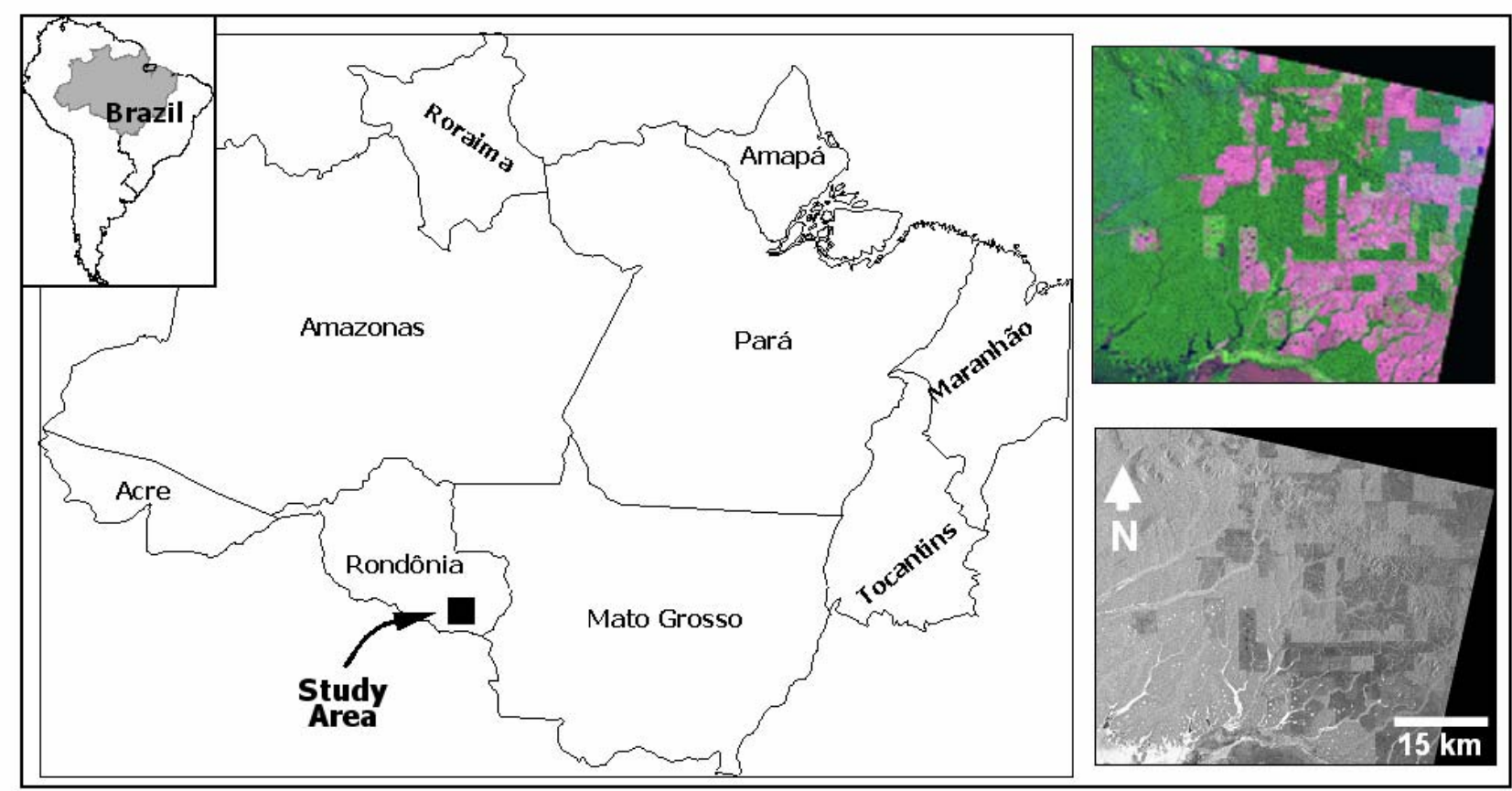

Figure 1. Location of the study area in Rondônia State, Brazilian Amazônia, and general characteristics of land use/land cover in the study area, as seen in a Landsat-TM color composite and a JERS-1 SAR image acquired in August 1997.

Table 1. JERS-1 SAR and Landsat TM images used in this study.

\begin{tabular}{l|l}
\hline \multicolumn{1}{c|}{$\begin{array}{c}\text { JERS-1 SAR } \\
\text { Images }\end{array}$} & \multicolumn{1}{c}{$\begin{array}{c}\text { Landsat TM } \\
\text { Images }\end{array}$} \\
\hline 30 September 1993 & 19 June 1993 \\
09 February 1994 & 09 August 1994 \\
04-August 1994 & 13 September 1995 \\
18 October 1995 & 13 July 1996 \\
25 May 1996 & 01 August 1997 \\
17 November 1996 & \\
29 March 1997 & \\
12 May 1997 & \\
25 June 1997 & \\
08 August 1997 & \\
\hline
\end{tabular}

\section{IMAGE PROCESSING AND INTERPRETATION}

The Landsat TM images were used to support the interpretation of the multitemporal SAR scenes. Based on satellite ephemeris, the 1993 TM image was geometrically corrected to the Universal Transverse Mercator (UTM) coordinate system, using a first-degree polynomial algorithm. This scene was used as reference to co-register the other TM images. In all cases, the co-registration accuracies were better than 0.8 pixel. The land cover map was obtained by digital classification of Landsat TM images following the procedure presented by Shimabukuro et al. (1998), which is based on image segmentation using a region growing algorithm, followed by unsupervised classification, and post-classification image editing. This 
procedure minimizes the omission and commission errors of the classification according to Almeida-Filho and Shimabukuro (2002). Land cover classes included: (i) primary forest, (ii) savanna, (iii) deforested (clear-cut) areas, and (iv) flooded vegetation. These image dataset allowed to estimate temporal changes in the land cover classes, such as the classes of burned grassland and burned forest converted to deforested areas, as well as the increment of deforested areas from one year to another.

The JERS-1 SAR operated in L-band frequency (wavelength of $23.5 \mathrm{~cm}$ ), with $\mathrm{HH}$ polarization and right-looking off-nadir angle of 35 degrees. The ground resolution was $18 \mathrm{~m}$ in both range and azimuth directions, and the swath width $75 \mathrm{~km}$. The ten JERS-1 images selected for this investigation were processed to standard level 2.1, i.e., 16 bits ground range, three looks and a pixel spacing of $12.5 \times 12.5 \mathrm{~m}$. Several adaptive and non-adaptive filters were tested to reduce speckle noise in the SAR images. The best results in terms of minimum loss of textural information and preservation of edges, estimated by visual inspection, were obtained with a 5 by 5 window Gamma Filter as implemented in ENVI software (Shi and Fung, 1994). All JERS-1 SAR images were then co-registered to the georeferenced TM images and resampled to the same spatial resolution (pixel $30 \mathrm{~m}$ x $30 \mathrm{~m}$ ). The August 1997 JERS-1 SAR DNs (digital number) were converted to backscatter coefficient $\left(\sigma^{\circ}\right)$ using Equation 1 (Rosenqvist, 1996; Shimada, 2001).

$$
\sigma^{\mathrm{o}}=10 \log 10\left(\sum(\mathrm{DN}) 2 / \mathrm{n}\right)+\mathrm{CF}[\mathrm{dB}]
$$

where $\mathrm{DN}=$ digital number of image pixels; $\mathrm{n}=$ number of pixels sampled and $\mathrm{CF}=$ calibration factor. The calibration factor was -85.34 according to the processing date of the SAR image (Shimada, 2001).

Shimabukuro et al. (2007) showed that land use/land cover classes identified simultaneously in Landsat TM (soil, vegetation and shade faction images) and JERS-1 SAR images presented a very good relationship $\left(r^{2}=0.82\right)$. Based on these results, a JERS-1 multitemporal time series analysis was conducted, involving the mapping of deforestation in the study site. For this, a visual inspection of the SAR images was conducted, followed by the analysis of backscattering responses for each considered land use/land cover class identified simultaneously in the corresponding Landsat TM and SAR images. The availability of five JERS-1 SAR images, acquired over the period of November 1996 to August 1997 allowed performing an evaluation of this kind of data for detecting sequential deforestation areas.

\section{RESULTS AND DISCUSSION}

Figure 2 shows the distinctive backscattering $(\mathrm{dB})$ values of the corresponding land cover classes identified in the 1997 Landsat TM image. These coefficient values confirm a high contrast among forest (medium gray), flooded vegetation (bright gray), and cleared areas (dark gray), as showed in the JERS-1 SAR image acquired on 08 August 1997. Forest and flooded vegetation presents higher backscattering response as compared with savanna and clear cuts areas. These results indicate that possibility exists for discriminating forested areas and deforestation as required by the INPE's PRODES Project (INPE, 2007). Figure 3 compares the classes identified in the JERS-1 SAR image with its temporally corresponding Landsat TM image, showing that both are very similar in remote sensing information content. 


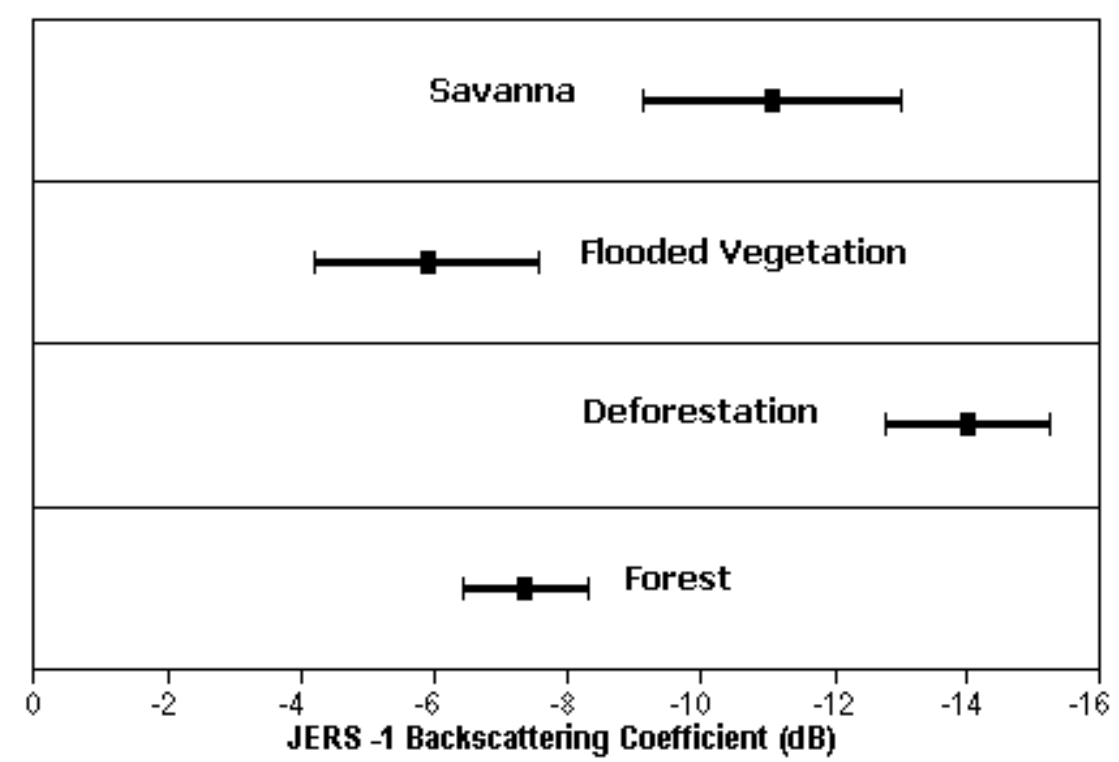

Figure 2. 1997 JERS-1 SAR Backscattering values for the samples of the land cover classes.
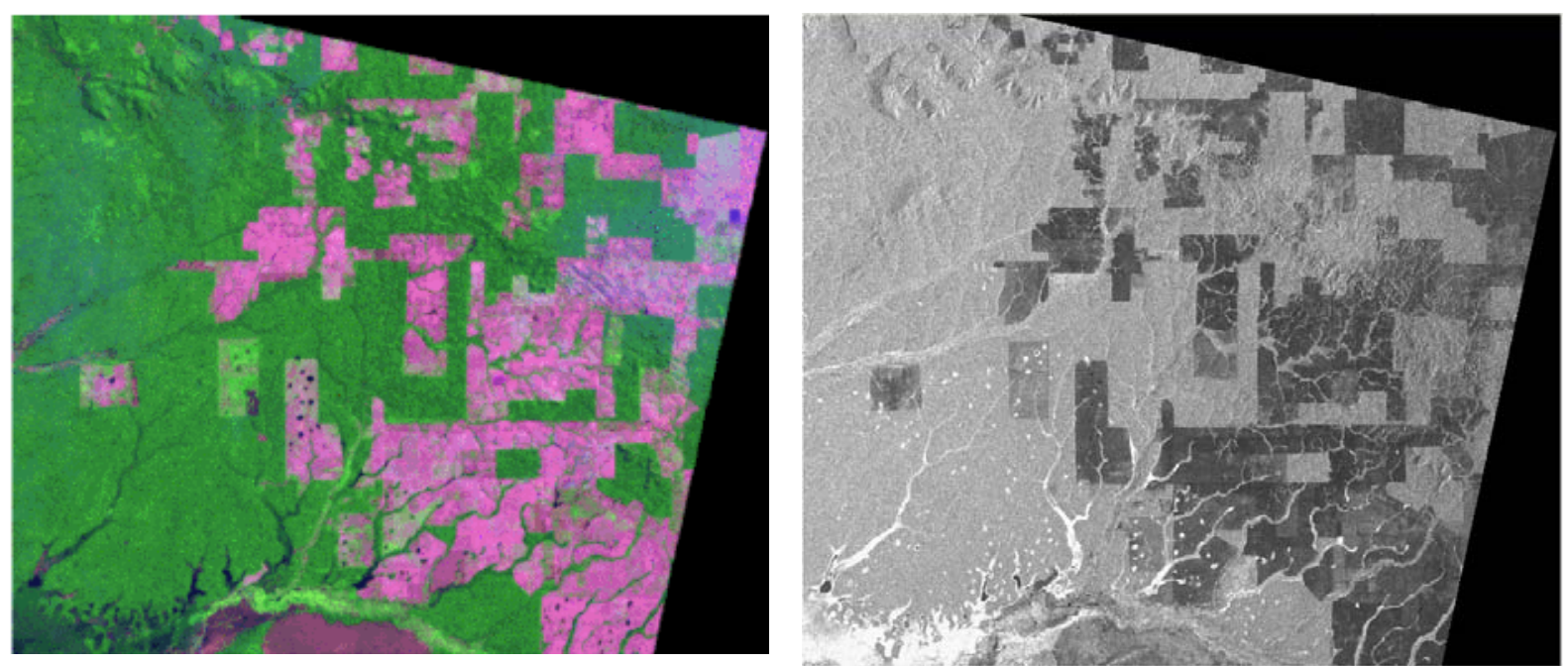

Figure 3. Landsat TM color composite (01 August 1997) and JERS-1 SAR image (08 August 1997).

Figure 4 shows the land use/land cover map of the study area derived from Landsat TM images acquired between 1993 to 1997 time period. This Figure presents a temporal map of the deforestation areas that occurred during this period, with the approximate time/year of clear-cutting, referred as "increment" as it "adds" to the areas already mapped as deforestation. This product is very similar to the one released by INPE's PRODES project (INPE, 2007) and was used to mask deforested areas in the SAR images. Table 2 shows the areas occupied by the land cover areas in the study area.

The areas recently burned, seen at the TM image acquired on 13 September 1995, as dark purple (in the TM image), appear as bright gray in the SAR data, being detectable easily by an interpreter (Figure 5). Although not presented here, in a careful inspection of the temporal JERS-1 SAR data, the history of clearings seen in Figure 5, with the approximate age of cleared areas, could also be observed. Then areas cleared initially by burning and with remaining biomass on the ground were seen as bright tones, while dark gray areas were 
related to bare soil (prepared for crop plantation), pastures or complete deforestation. In addition, the availability of 5 JERS-1 images, acquired between November 1996 and August 1997, allowed observing an increase of some deforested areas from 1996 to 1997 time period.

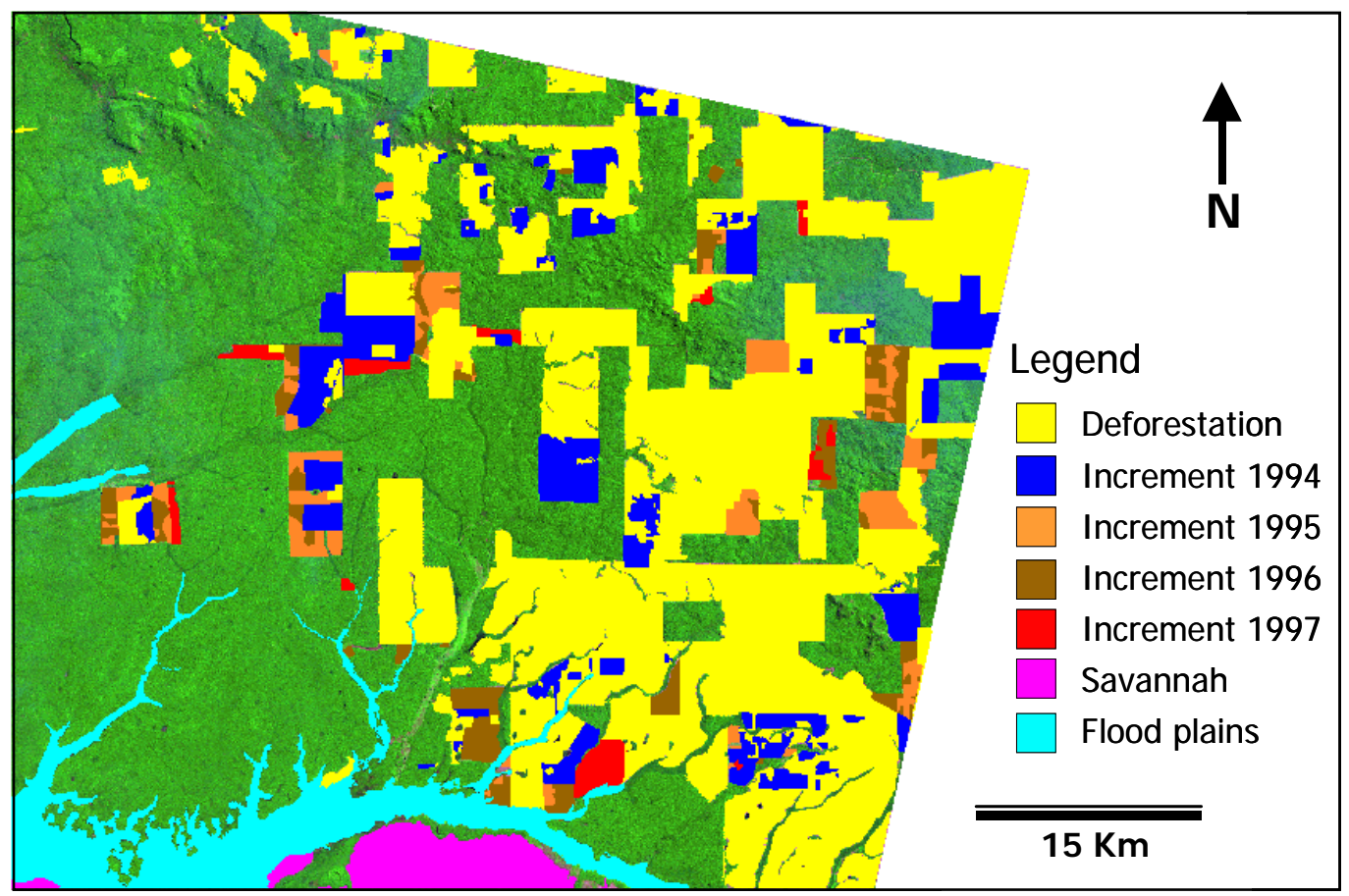

Figure 4. Land cover map of the study area based on classification of Landsat TM time series (Forest areas showed in green in the 1997 TM (R5 G4 B3) color composite image).

Table 2. Land cover areas estimated by multitemporal analyses of Landsat TM images.

\begin{tabular}{|c|c|c|c|c|c|}
\hline Classes & $\begin{array}{c}\text { TM- } 1993 \\
\left(\mathrm{Km}^{2}\right)\end{array}$ & $\begin{array}{c}\text { TM- } 1994 \\
\left(\mathrm{Km}^{2}\right)\end{array}$ & $\begin{array}{c}\text { TM- } 1995 \\
\left(\mathrm{Km}^{2}\right)\end{array}$ & $\begin{array}{c}\text { TM- } 1996 \\
\left(\mathrm{Km}^{2}\right)\end{array}$ & $\begin{array}{c}\text { TM- } 1997 \\
\left(\mathbf{K m}^{2}\right)\end{array}$ \\
\hline Forest & 2384.53 & 2215.36 & 2151.65 & 2085.65 & 2059.54 \\
\hline Deforestation & 925.70 & 925.70 & 925.70 & 925.70 & 925.70 \\
\hline Flooded areas & 194.40 & 194.40 & 194.40 & 194.40 & 194.40 \\
\hline Savanna & 57.72 & 57.72 & 57.72 & 57.72 & 57.72 \\
\hline Increment-94 & 0.00 & 169.24 & 169.24 & 169.24 & 169.24 \\
\hline Increment-95 & 0.00 & 0.00 & 63.71 & 63.71 & 63.71 \\
\hline Increment-96 & 0.00 & 0.00 & 0.00 & 66.01 & 66.01 \\
\hline Increment-97 & 0.00 & 0.00 & 0.00 & 0.00 & 26.11 \\
\hline
\end{tabular}

For an operational monitoring program of tropical forest, previous information on deforestation (as the maps produced by PRODES project) can be used to mask deforestation areas in SAR images, using SAR data as a base to map only new clear cuttings. Then a monitoring procedure can be sought with SAR images. The results show that SAR imagery is an alternative source of information for an operational project for deforestation monitoring especially for the areas with cloud cover restricting the use of optical images. 

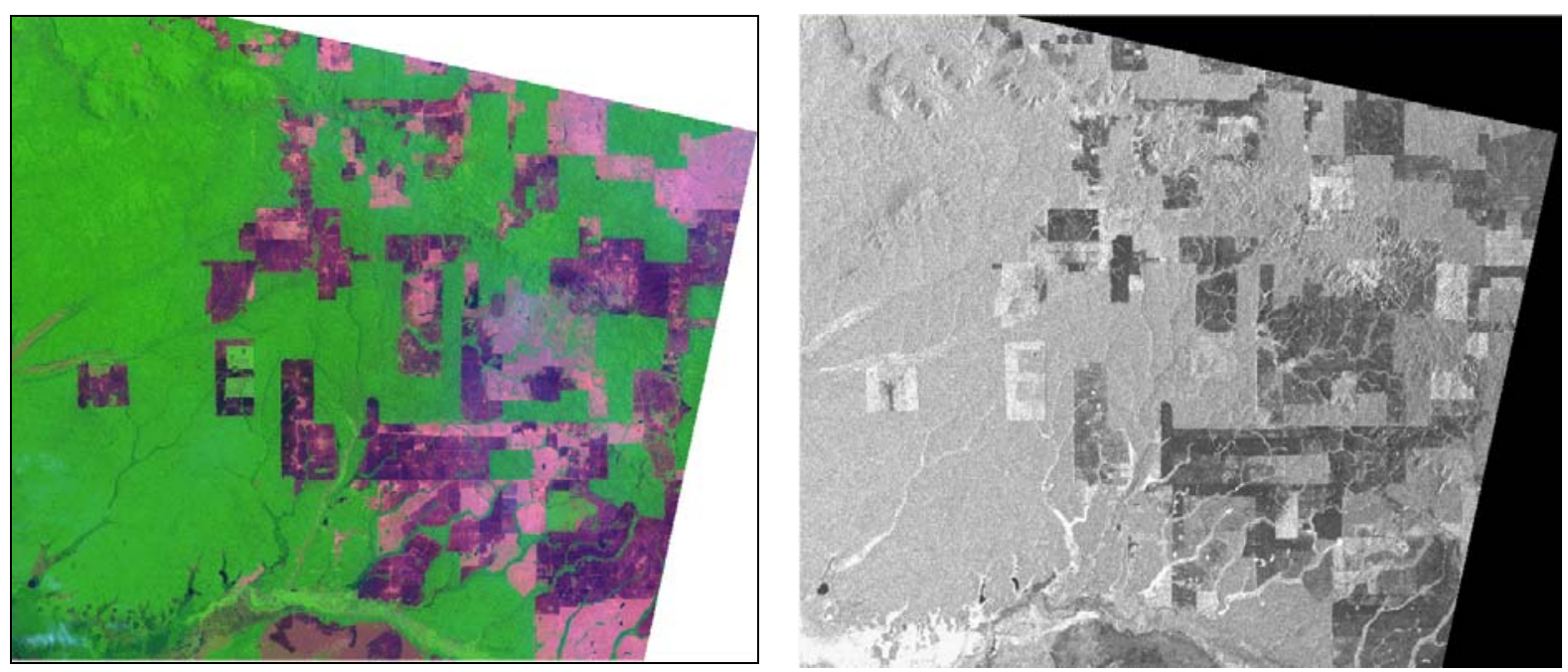

Figure 5. Landsat-TM color composite (13 September 1995) and JERS-1 SAR image (18 October 1995).

\section{CONCLUSIONS}

JERS-1 SAR images showed that deforested areas are well-identified due to a low backscattering response (as expected), while areas that have been cleared and even burned but with remaining forest material left on the ground present high backscattering response. Considering these observations and user interpretation expertise, it is evident that JERS-1 images may be used to map and monitor land cover changes in Amazônia. Then using an initial assessment of deforestation as available in the PRODES website, the JERS-1 SAR data is a useful source of information for monitoring deforestation activities in Amazônia, considering that its acquisition does not depend on weather condition.

\section{ACKNOWLEDGEMENT}

We acknowledge the Conselho Nacional de Desenvolvimento Científico e TecnológicoCNPq for research grants (305978/2006-3 and 306011/2006-9) and a scholarship grant (132140/2005-5). The Earth Observation Research and Application Center (EORC) of the Japan Aerospace Exploration Agency (JAXA) provided the JERS-1 SAR images within the framework of the Global Rain Forest Mapping (GRFM) Project. The National Institute for Space Research (INPE) provided the Landsat-TM images.

\section{REFERENCES}

ALMEIDA-FILHO, R.; SHIMABUKURO, Y. E. Digital processing of a Landsat-TM timeseries for mapping and monitoring degraded areas caused by independent gold miners, Roraima State, Brazilian Amazon. Remote Sensing of Environment, v. 79, p. 42-50, 2002.

ALMEIDA-FILHO, R.; ROSENQVIST, A.; SHIMABUKURO, Y. E.; SANTOS, J. R. Evaluation and perspectives of using multi-temporal L-band SAR data to monitor deforestation in the Brazilian Amazônia. IEEE Geoscience and Remote Sensing Letters, v. 2, n. 4, p. 409-412, 2005. 
INSTITUTO NACIONAL DE PESQUISAS ESPACIAIS. INPE. Projeto PRODES: monitoramento da floresta Amazônica Brasileira por satélite. 2007. Available: $<$ www.obt.inpe.br/prodes>. Access: February 2008.

ROSENQVIST, A. Evaluation of JERS-1/SAR and Almaz/SAR backscatter for rubber and oil palm stands in West Malaysia. International Journal of Remote Sensing, v. 17, p. 191-202, 1996.

SHI, Z.; FUNG, K. B. A comparison of digital speckle filters. In: GEOSCIENCE AND REMOTE SENSING SYMPOSIUM - IGARSS'94, August 8-12 1994, Pasadena. Proceedings... Piscataway: IEEE Press, 1994. p. 2129-2133.

SHIMABUKURO, Y. E.; BATISTA, G. T.; MELLO, E. M. K.; MOREIRA, J. C.; DUARTE, V. Using shade fraction image segmentation to evaluate deforestation in Landsat Thematic Mapper images of the Amazon region. International Journal of Remote Sensing, v. 19, p. 535-541, 1998.

SHIMABUKURO, Y. E.; ALMEIDA-FILHO, R.; KUPLICH, T. M.; FREITAS, R. M. Quantifying optical and SAR image relationships for tropical landscape features in Amazônia. International Journal of Remote Sensing, v. 28, p 3831-3840, 2007.

SHIMADA, M. User's Guide to NASDA's SAR products. Ver.3. Tokyo: NASDA, 2001. 23p.

STONE, T. A.; WOODWELL, G. M. Shuttle imaging radar analysis of land use in Amazonia. International Journal of Remote Sensing, v. 9, p. 95-105, 1988. 